\title{
PRESIDENDIKÕNEDE SARNASUSED JA ERINEVUSED: KRIITILINE TEKSTIANALÜÜS
}

\author{
MARIA TUULIK
}

\begin{abstract}
Annotatsioon. Artiklis uuritakse tekstianalüüsi meetodite abil presidentide Lennart Meri ja Arnold Rüütli uusaastakõnesid. Esitatakse protsesside analüüs, mis võimaldab vaadelda teksti stilistilist mõju dünaamilisuse-staatilisuse ja konkreetsuse-abstraktsuse skaalal, ning osaliste analüüs, mille puhul vaadatakse uusaastakõnedes esinenud osaliste rolle, nimetamist ja kategoriseerimist ning nende seostamist erinevate protsessiliikidega. Artikli teine pool käsitleb kõnede interpersonaalset funktsiooni, keskendudes mina-teie-tasandi suhtluse uurimisele ning kõneleja ja sõnumi suhetele. Analüüsitud tunnuste põhjal tuuakse välja Meri ja Rüütli uusaastakõnede põhilised sarnasused ja erinevused.
\end{abstract}

Võtmesõnad: tekstilingvistika, stilistika, funktsionaalne grammatika, viisakusstrateegiad, deiksis

Artikli eesmärk on selgitada tekstianalüüsi vahenditega presidentide Lennart Meri ja Arnold Rüütli uusaastakõnede mõjujõudu ja kuulajate kõnetamise võtteid. Presidendikõned on ühelt poolt institutsionaalsed sõnavõtud, mille koostamisel osalevad eeldatavasti paljud abilised, ja seetõttu on ootuspärane nende sisuline, vormiline ja diskursiivne sarnasus. Teiselt poolt on selline kõne ka presidendi isiklik pöördumine oma rahva poole, mistõttu kummagi presidendi isiksus peaks nii või teisiti esilduma tema kõnedes. Sellest aspektist on huvipakkuv uurida, milliste tunnuste poolest analüüsitavad tekstid üksteisega sarnanevad ja millised personaalsed tekstimoodustusvõtted nende isikupära peegeldavad. Artiklis vaadeldakse mõlema presidendi esimese ametiaja viit uusaastakõnet: Lennart Meri kõnesid aastatest 1992-1996 ja Arnold Rüütli kõnesid aastatest 2001-2005².

\footnotetext{
1 http://vp1992-2001.vpk.ee/

2 http://vp2001-2006.vpk.ee/et/
} 


\section{Taust}

Uusaastakõnede uurimise teoreetiline lähtepunkt on kriitiline tekstianalüüs ning selle käsitlus teksti tähistusfunktsiooni ja interpersonaalse funktsiooni kohta. Analüüs tugineb põhiliselt Norman Fairclough', Michael Alexander Kirkwood Halliday ja Eesti uurijatest Reet Kasiku töödele.

Kriitilise tekstianalüüsi uurimisvaldkonnaks on keelekasutuse ja sotsiaalse võimu suhted. Keelekasutust vaadeldakse sotsiaalselt ja kollektiivselt kujundatud nähtusena, kuid samas ka sotsiaalselt kujundava jõuna, mis mõjutab ümbritsevat maailma. Kriitilise tekstianalüüsi kohaselt kujundab keelekasutus väärtusi ja teadmisi, rühmadevahelisi suhteid ja sotsiaalseid identiteete. Keelt käsitletakse kui sotsiaalset areeni, kus samal ajal toimub maailma konstrueerimine ja suhtlus. Uurimisobjektiks on see, mil viisil keel kodeerib ideoloogiat; kuidas situatsiooni, protsesse, osalisi ja nende omavahelisi suhteid esitatakse. (Kasik 2002: 74-76)

Ideoloogilisuse kõrval peetakse kriitilises tekstianalüüsis oluliseks teksti polüfunktsionaalsust. Keele omadusena nähakse peale maailma ja kogemuste kirjeldamise ka võimet luua tekste ja olla inimestevaheliseks suhtlusvahendiks. Sellega seoses eristatakse iga teksti puhul korraga kolme metafunktsiooni: tähistusfunktsiooni, interpersonaalset funktsiooni ja tekstuaalset funktsiooni (Halliday 1994: 179-180). Artiklis analüüsitakse presidendikõnesid tähistusfunktsiooni ja interpersonaalse funktsiooni aspektist.

Tähistusfunktsiooni analüüsi eesmärk on selgitada, millise pildi tekst loob maailmast ja kogemustest, keskendudes sellele, kuidas tegelikkust tekstides konstrueeritakse; protsesse ja osalisi tekstis nimetatakse. Tähistusfunktsiooni alla kuulub teksti informatsiooni valik, mis on alati seotud vaatenurgaga, kuna seda kujundavad koostaja kogemused, väärtus- ja suhtumissüsteemid ning kokkukuuluvus teatud sotsiaalsete rühmadega. (Kasik 2008: 17-18)

Keelekasutaja poolt tehtud valikuid analüüsides on võimalik selgitada, missugune on teksti maailmapilt. Tegemist pole enamasti teadlike, vaid pigem automaatsete valikutega, kus keelekasutaja toetub keele ressurssidele ja kinnistunud tähenduste süsteemile. (Kukk 2001: 146)

Artiklis uuritakse täpsemalt kahte tähistusfunktsiooni nähtust, mida on tekstianalüüsi meetoditega võimalik analüüsida: 1) osaliste nimetamist ja kategoriseerimist ning 2) protsessiliike ja osaliste rolle. Osaliste nimetamist ja kategoriseerimist vaadeldakse Theo van Leeuweni (1996: 
32-70) kategooriate põhjal ning protsesside liigitus toetub Halliday (1994: 106-119) funktsionaalsele grammatikale.

Kriitiline tekstianalüüs keskendub osaliste kategoriseerimist uurides leksikaalsete valikute rollile. Sageli on nimetamise analüüsi kasulik kombineerida protsesside analüüsiga, et vaadata, millised osalised missugusel moel millistes protsessides figureerivad. (Fairclough 1995: 27)

Funktsionaalne grammatika käsitleb reaalsust kui protsesside kogumit, mida saab vaadelda lause struktuurist. Grammatika eristab välise maailma protsesse, mis lähtuvad välisest kogemusest, ja teadvuse protsesse, mis johtuvad sisemisest kogemusest. Neid nimetatakse vastavalt materiaalseteks ja mentaalseteks protsessideks. Kolmanda kategooriana tuuakse sisse abstraktsemad suhteprotsessid, mis hõlmavad võimet üldistada ja järeldusi teha. Need kolm kategooriat on tähtsaimad protsessitüübid (Halliday 1994: 107).

Materiaalsed protsessid on tegevusprotsessid, mis väljendavad mingi entiteedi tegutsemist (mõne teise entiteedi suhtes) ning ka üldisemalt muutust või liikumist. Mentaalsed protsessid sisaldavad tajujat ja tajutavat (nähtust). Seal on üks osaline alati inimene või miski, millele on omistatud inimlikud jooned, kes või mis tunneb, mõtleb, tahab jne. Suhteprotsesse võiks nende seisundit kirjeldava iseloomu järgi kutsuda ka olemisprotsessideks. Suhteprotsessides on olemisel kaks osapoolt: miski öeldakse olevat midagi muud. Kahe entiteedi vahel seatakse üles teatud suhe, mis võib olla näiteks atributiivne, identifitseeriv või possessiivne (Halliday 1994: 109-119).

Peale nimetatud protsesside eksisteerivad ka vaheprotsessid, mis asuvad peakategooriate piirialadel ning sisaldavad tihti kahe põhiprotsessi jooni. Materiaalsete ja mentaalsete protsesside vahepeal on käitumisprotsessid, mille alla kuuluvad sisemiste protsesside välisilmingud. Mentaalsete ja suhteprotsesside vahele jäävad aga verbaalsed protsessid, mis seovad teadvust ja keelevorme (Halliday 1994: 107).

Interpersonaalne funktsioon keskendub sellele, kuidas tekstid toimivad suhtluses ja missugused suhtluseesmärgid neis sisalduvad. Sealjuures on peamine eesmärk vaadata, kuidas kirjutaja kasutab keelt, et oma hinnanguid, suhtumisi ja kommentaare esitada ning kuidas ta seeläbi lugejaga suhestub (Kasik 2008: 28-30).

Keelekasutuses loodavate identiteetide abil moodustab keelekasutaja endale mingi rolli ja määrab ka lugeja või kuulaja rolli teksti vastuvõtjana. 
Diskursuserollid väljenduvad tekstis keeleliste joonte kaudu ning lugeja saab vastavate sõnavaraliste ja grammatiliste tunnuste abil järeldada, millise rolli on autor endale konstrueerinud. Kasiku järgi (2008: 30-31) on näiteks meediatekstides tavalisemad vahendaja, teadja, õpetaja ja kritiseerija positsioon.

Interpersonaalse funktsiooni võib jagada suhtlustähenduseks ja suhtumistähenduseks. Suhtlustähendus väljendab kirjutaja ja lugeja vahelisi suhteid ning seostub osaliste rollidega. Suhtumistähendus hõlmab kirjutaja ja sõnumi suhteid. Kui suhtlustasandil saab vaadelda, kuidas tekst oma keeleliste joontega kirjutaja ja lugeja rollid määrab, siis suhtumistasandi analüüs jälgib neid keelejooni, millega tekstitootja öeldu tõesust, võimalikkust ja väärtust hindab. (Fairclough 1989: 110)

Interpersonaalse funktsiooni juures esitatakse artiklis nii suhtlus- kui ka suhtumistasandi analüüs. Suhtlustähenduse puhul uuritakse kõnede personaalsust: kuivõrd aktiivselt suhtleb kõneleja kuulajaga mina-teietasandil. Vaadatakse, kuidas presidendid kuulajate poole pöörduvad, analüüsitakse kõnede mina-osalise rolle ja protsesse ning tuuakse välja peamised diskursuserollid, milles kõnelejad esinesid. Selgitatakse ka omadusi ja positsioone, mida kõnelejad kuulajatele konstrueerisid.

Suhtumistasandil selgitatakse kõneleja ja sõnumi suhteid, kirjeldatakse modaalsust, millega kõnelejad väljendasid oma suhtumist kõnealustesse teemadesse.

\section{Protsesside analüüs}

Protsesside analüüsi eesmärk on vaadelda teksti stilistilist mõju dünaamilisuse-staatilisuse ja konkreetsuse-abstraktsuse skaalal. Selleks jagati kõnedes esinenud protsessid kõigepealt kahte rühma aktiveerituse ja passiveerituse alusel ning seejärel omakorda protsessiliikidesse. Aktiveeritud protsessideks määrati verbid, mis esinesid pöördelises vormis öeldisena ehk aktiveeritud kujul. Passiveeritud protsessideks on tarinditena sisestatud vormid, näiteks nominalisatsioonid ja adjektivatsioonid, samuti adverbalisatsioonidena tõlgendatavad lauselühendid.

Presidentide Lennart Meri ja Arnold Rüütli uusaastakõnede protsessianalüüsis liigitati kokku 1256 protsessi, millest 630 esines president Meri kõnedes ja 626 president Rüütli kõnedes. Valdavalt esinesid protsessid aktiveeritud kujul. President Meri kõnedes moodustasid aktiveeritud 
protsessid 94\% (594 esinemiskorda) ja passiveeritud protsessid 6\% (36 esinemiskorda). President Rüütli kõnedes oli aktiveeritud pöördeliste verbivormidena esitatud 548 protsessi (88\%) ja passiveeritud kujul 78 protsessi (12\%). Kuna aktiveeritud tegevusverbid teevad teksti stiili dünaamilisemaks ning nominalisatsioonid ja infiniitvormid staatilisemaks, näitab analüüs, et Lennart Meri uusaastakõned olid mõnevõrra dünaamilisemad ja Arnold Rüütli kõned mõnevõrra staatilisemad.

Aktiveeritud protsesside puhul domineerisid materiaalsed protsessid nii Meri kui ka Rüütli kõnedes. Sellest järeldub, et mõlemad presidendid representeerisid osalisi kõige sagedamini tegevusprotsessides, kus väljendati kellegi või millegi tegutsemist kellegi või millegi suhtes, aga ka üldisemalt liikumise ja muutumisega seotud olukordades (näited 1, 2).

(1) Eesti kui suveräänse riigi usaldusväärsus on kasvanud. (Meri 1992)

(2) Ent nüüd võtkem oma armsad inimesed hästi enda ligi .. (Rüütel 2004)

Suuruselt järgmised rühmad aktiveeritud protsesside seas olid suhteprotsessid, mida leidus rohkem president Meril (31\%) (näide 3), ja mentaalsed protsessid, mida tuli enam ette president Rüütlil (28\%) (näide 4). Sageduselt kolmandaks jäid president Meril mentaalsed protsessid (23\%) (näide 5) ja president Rüütlil suhteprotsessid (23\%) (näide 6).

(3) Eestlased on rikka ajalookogemusega väike rahvas. (Meri 1996)

(4) Lapsed mõistavad ja armastavadki isamaad .. (Rüütel 2005)

(5) Tahaksin, et mõistaksite lihtsat tõde .. (Meri 1996)

(6) Samas oli rahvahääletuse tulemus ka kultuuriline enesemääratlus .. (Rüütel 2003)

Selline jaotumine näitab, et olukorra kirjeldamist oli rohkem Meri kõnedes ning mõtete, tunnete ja soovide väljendamist Rüütli kõnedes. Mentaalsetest protsessidest moodustasid mõlema presidendi kõnedes arvestatava osa modaalverbidega väljendid, kus kõneleja väljendas oma hinnangut tegevuse toimumise kohustuslikkuse, vajaduse, võimalikkuse või tõenäosuse kohta. Vaheprotsessidest moodustasid suurima rühma verbaalsed protsessid, mida ilmnes president Meril peaaegu poole rohkem (7\%) kui president Rüütlil (4\%). 
Tabel 1. Aktiveeritud protsesside jaotumine uusaastakõnedes

\begin{tabular}{|l|c|c|c|c|}
\hline \multirow{2}{*}{$\begin{array}{c}\text { Aktiveeritud } \\
\text { protsessid }\end{array}$} & \multicolumn{2}{|c|}{ Lennart Meri kõned } & \multicolumn{2}{c|}{ Arnold Rüütli kõned } \\
\cline { 2 - 5 } & $\begin{array}{c}\text { Esinemus } \\
\text { kordades }\end{array}$ & $\begin{array}{c}\text { Protsent } \\
(\%)\end{array}$ & $\begin{array}{c}\text { Esinemus } \\
\text { kordades }\end{array}$ & $\begin{array}{c}\text { Protsent } \\
(\%)\end{array}$ \\
\hline Materiaalsed protsessid & 230 & $\sim 39 \%$ & 241 & $\sim 44 \%$ \\
\hline Mentaalsed protsessid & 135 & $\sim 23 \%$ & 150 & $\sim 28 \%$ \\
\hline Suhteprotsessid & 186 & $\sim 31 \%$ & 128 & $\sim 23 \%$ \\
\hline Verbaalsed protsessid & 40 & $\sim 7 \%$ & 24 & $\sim 4 \%$ \\
\hline Käitumisprotsessid & 0 & 0 & 5 & $\sim 1 \%$ \\
\hline
\end{tabular}

Passiveeritud protsesside hulgas olid mõlemal presidendil suures ülekaalus materiaalsed protsessid (Meril 83\% ja Rüütlil 82\%) (näited 7, 8).

(7) .. teisisõnu tema mõju riigitöös, õigusriigi kujundamisel .. (Meri 1992)

(8) Pean silmas meie sõdurite hukkumist liitlaskohustuste täitmisel .. (Rüütel 2004)

Nii aktiveeritud kui ka passiveeritud materiaalsete protsesside puhul moodustasid uusaastakõnedes enamiku abstraktsed protsessid. See tähendab, et uusaastakõnedes ei pööratud tähelepanu mitte niivõrd isikute ja institutsioonide konkreetsetele, füüsilistele tegudele, vaid üldistatud, abstraktsetele tegevustele (näited 9, 10).

(9) .. et Eesti taastab oma iseseisva riigi .. (Meri 1993)

(10) Laste kasvatamisel ühendagem mitme põlvkonna teadmised .. (Rüütel 2005)

Protsesside analüüsil uuriti ka seda, kui palju oli aktiveeritud ja passiveeritud protsessides primaarset osalist (tegijat, olijat) nimetatud ja kui palju nimetamata jäetud. Protsesse, kus primaarne osaline oli nimetamata, leidus president Meri kõnedes 47 (7\%) ja president Rüütli tekstides 63 $(10 \%)$ (näited 11, 12).

(11) Lõppenud aastal tõusis korduvalt küsimus poliitilisest eetikast. (Meri 1996)

(12) Ollakse üksteisest käe-, silma- või kuuldeulatuses. (Rüütel 2002) 
Kuna nii aktiveeritud kui ka passiveeritud protsessides esines osalise nimetamata jätmist rohkem president Rüütli kõnedes, saab sellele tuginedes pidada president Meri kõnesid mingil määral konkreetsemaks ja president Rüütli kõnesid veidi abstraktsemaks.

Uurimisel selgus, et passiveeritud protsessides jäi mõlema presidendi kõnedes primaarne osaline nimetamata oluliselt sagedamini kui aktiveeritud protsessides, mis on osaliselt tingitud juba passiveeritud protsessi keelelisest struktuurist. Nimetamata osalistega protsesside abil jagati kõnedes tegutsemissoovitusi nii kuulajatele kui ka valitsusele. Osalise väljajätmine aitas sel juhul kompenseerida nõudmisi, mida kõneleja püstitas, sest otsese pöördumise vältimisega sai esitada oma korraldusi kaudsemalt (näited 13, 14).

(13) Nende ja muude ohtude teadvustamine on saabuva aasta aja käsk. (Meri 1995)

(14) See on võimalik, kui mõistetakse, et valitsemine tähendab eeskätt vastutust mitte iseenda, oma erakonna või huvirühma, vaid Eesti riigi ees. (Rüütel 2001)

Aktiveeritud protsessides jäeti osalised sageli nimetamata kontekstis, kus kõneleja noomis ja manitses. Manitsemisobjektiks võis olla kogu kuulajaskond (näide 15), sellisel puhul lubas osalise väljajätmine esitada kõnelejal tugevamaid hinnanguid, samas võimaldades kuulajatel end vähem puudutatuna tunda. Kuid enamasti ei olnud võimalik täpselt kindlaks määrata, kellele manitsused mõeldud olid (näited 16, 17).

(15) Ei tohiks ju olla ületamatult raske näidata inimlikku suurust .. (Rüütel 2004)

(16) Kui jõuallikad on viidud vastavusse võimalustega, siis pole vaja lõputult kiirendada ja katsetada. (Rüütel 2003)

(17) Riigis tuleb asju nimetada õigete nimedega. (Meri 1995)

Vahel kaasnes agendi väljajätuga veel vastutuse hämardamine. Passiveeritud protsessides võis agendi nimetamata jätmist täheldada negatiivseid tagajärgi toonud või muidu negatiivsete aspektidega seonduvate protsesside korral, kus välditi nimetamast valitsust, riigikogu, poliitikuid või muid otsustajaid. Selliseid protsesse esitati kui iseeneslikke, tekstist ei selgunud, kes negatiivseid tagajärgi toonud protsessi toimumise eest vastutab (näide 18). 
(18) Eesti lootust varjutab samas erastamise ja maareformi aeglus, hüpoteegiseaduse viibimine ning sellest siginev ebakindlus. (Meri 1992)

\section{Osaliste analüüs}

Osaliste analüüsil vaadatakse, 1) milliseid osalisi esitatakse pigem aktiivsete tegutsejatena, milliseid pigem seisundis ja passiivsetena; 2) milliste protsessiliikidega eri osalisi seostatakse; 3) kuidas osalisi kõnedes nimetatakse ja kategoriseeritakse ning 4) kuidas luuakse ühtekuuluvustunnet.

Analüüsi süsteemsemaks esituseks jagati osalised sisulistesse koondrühmadesse. Eristati kahte suurt koondrühma: MEIE ja MAAILM, sealjuures MEIE all käsitleti eraldi meie-pronoomeniga väljendatud osalisi (meie-osalist) ning Eesti kaudu determineeritud osalisi (Eesti, Eesti Vabariik, eestlased, eesti rahvas jne).

MAAILMA analüüsis vaadeldi kõiki ülejäänud osalisi, mis MEIE alla ei kuulunud (teised riigid, üksikisikud, institutsioonid jne), välja arvatud suhtlusfunktsiooni väljendavad mina- ja teie-osaline, keda uuriti interpersonaalse funktsiooni analüüsi peatükis. Niisiis loeti MAAILMA-rühma osalised, kes jäävad kõneleja ja kuulajate ühisrühmast väljapoole, MEIErühma aga osalised, mis hõlmavad kõnelejat ja kuulajaid ühiselt.

Samuti uuriti meie-deiktikute viiteala, kus vaadati, kes enamasti meie viitealasse kuuluvad, ning prooviti sõnastada põhilised eesmärgid, mida meie-kasutus uusaastakõnedes täidab. Meie-osalisega seoses tuleks põgusalt tutvustada deiksise olemust. Renate Pajusalu järgi (1999: 17) on deiksis nähtus, mis seob keelt ja konteksti, keelesisest ja keelevälist maailma. Deiktikud on kõige pragmaatilisemad sõnad, mille tähendusse kuulub kõnesituatsioonis viitamine. Nii nagu teistes keeltes on meie-deiksis ka eesti keeles kollektiivi väljendaja, viidates isikute hulgale, mis teatud etapil kõneleb, mõtleb, tunneb või tegutseb ühtemoodi. (Pajusalu 1999: 56)

Yael-Janette Zupnik (1994: 339) toob välja, et esimese isiku mitmuslik asesõna meie võib täita võimsat veenmisfunktsiooni, kui kõneleja oskab kodeerida teatud grupi liikmeks olekut ehk siis viidata eri gruppidele asesõna meie ulatusalas kui kaasaarvatuile.

Zupnik toob deiktikute puhul välja kaks solidaarsust tekitavat funktsiooni, millest üks võimaldab kuulajal siseneda kõneleja kultuurimudelisse ja teine pehmendab minapilti ähvardavaid kõneakte. Viimane on seotud lingvistilise viisakuse tavadega, mille eesmärkideks on heakskiidu 
kaudu hooldada kuulaja(te) positiivset minapilti ning samal ajal arvestada ka negatiivse minapildiga, mis soovib olla sõltumatu ja iseseisev, tundes ennast ohustatuna kõiksugustest nõudmistest. (Zupnik 1994: 341-343)

Kõnedes esines meie-pronoomeniga väljendumist Eesti kaudu nimetatud osalistest sagedamini, kokku moodustasid MEIE-rühmast ligikaudu 2/3 meie-pronoomeniga väljendid (näited 19,20) ja ligikaudu 1/3 Eesti kaudu determineeritud osalised (näited 21, 22).

(19) Me ei saa lubada endale poliitikute küünilist ja vastutustundetut mängu. (Meri 1996)

(20) Nõnda võib öelda, et loome oma laste tulevikku iga hetk ..(Rüütel 2005)

(21) Kõige kaunim on naeratav Eesti. (Meri 1993)

(22) Eesti rahvas on välja tulnud ajalookatsumustest. (Rüütel 2002)

Meie ja Eesti kaudu nimetatud osalised erinevad ka oma stilistilise mõju poolest. Meie mõjujõud on suurem, kuna see viitab deiktiliselt ja seob kõneleja-kuulaja ühtseks subjektiks. Eesti kaudu nimetamine on distantseeritum ja objektilisem ning jätab kõneleja-kuulaja ühtsuse tagaplaanile. Seega näitas meie-vormiga väljendumise eelistatus, et kõnelejad soovisid oma kuulajaid tugevamalt mõjutada ja kaasa haarata.

MEIE analüüsil selgus, et meie-osalise ja Eesti kaudu determineeritud osaliste aktiivsus ja passiivsus jagunes kõnedes erinevalt. Meie-osalise aktiivsete ja passiivsete rollide jaotumine tekstides oli väga ühtlane, aktiivseid rolle esines mõlema presidendi kõnedes 75 , passiivseid rolle oli aktiivsetest pisut vähem: Meril 71 ja Rüütlil 74. Eesti kaudu määratletud osalisi esitati passiivsetes rollides palju suuremal määral: president Meri kõnedes passiivselt 90 korda ja aktiivselt 12 korda, president Rüütli kõnedes passiivselt 58 korda ja aktiivselt 11 korda.

MEIE-rühmas eelistati aktiivsete materiaalsete ja mentaalsete protsesside kaudu väljendumisel meie-vormi. Kui meie-osalist esitati suhteliselt võrdselt nii tegutsejana materiaalsetes protsessides, kogejana mentaalsetes protsessides kui ka seisundis olevana suhteprotsessides, siis Eesti kaudu määratletud osalised seostati uusaastakõnedes enamasti seisundiprotsesside ja passiivsete konstruktsioonidega.

Meie viiteala analüüs näitas, et põhiliselt taheti meie-vormiga rõhutada presidendi, kuulajate ja riigi kokkukuuluvust. Püüti luua ühist identiteeti, 
mis aitaks kuulajatel end väljendatud protsessidest osavõtjatena tunda. Meie-deiktikut kasutati sageli rahvustunnet loova elemendina tähendustes „meie kui riik” ja „meie kui rahvus, eestlased”. Meie kasutust sai vaadelda veel kriitika pehmendajana, kuna sel moel võis kõneleja näidata ka ennast justkui olevat osaliste hulgas, keda kritiseeritakse. Meie-vorm võimaldas uusaastakõnedes esitada oma seisukohta kui meie oma ning näidata end rahva nimel tegutsejana.

MAAILMA esitati uusaastakõnedes enamasti aktiivses rollis, põhiliselt materiaalsete või mentaalsete protsessidega seotult, vähemal määral ka verbaalsetes protsessides. MAAILMA passiivsetes rollides olid valdavad suhteprotsessid, sageduselt teise kategooriana esinesid materiaalsed ja kolmandana mentaalsed protsessid. MAAILMA esitati mõnevõrra rohkem aktiivsetes rollides kui MEIE-rühma ning nendel puhkudel, kus MEIE oli MAAILMA suhtes aktiivses positsioonis, eelistati meie-osalisega väljendumist Eesti kaudu determineeritud osalise kasutamisele.

MAAILMA ja Eesti kaudu determineeritud osaliste puhul analüüsiti ka nimetamist ja kategoriseerimist. Mõlemas rühmas esitati osalisi kõige rohkem kollektiveeritult, mis võimaldas viidata neile kui homogeensele tervikule. Eesti kaudu determineeritud osaliste puhul esines sageli samaviitelisust meie-osalisega. Indetermineerimine esines osaliste seostamisel negatiivsete aspektidega ning selle eesmärk võis olla soov kriitikat üldisemaks ja seeläbi pehmemaks muuta (näited 23, 24).

(23) .. et nii mõnigi riigiametnik on Eesti Vabariigi häbi. (Meri 1996)

(24) Mõne Ida-Euroopa riigi kohta võib öelda, et seal ei ole mitte niivõrd demokraatia võitnud kuivõrd totalitarism kaotanud. (Meri 1993)

Peale assimileeritud rühmade avaldus MAAILM kõnedes tihtipeale kas riikide ühenduste ja lokaalsete üksuste kujul või metafoorsete osalistena, mille puhul abstraktseid entiteete kujutati iseseisvate toimijatena. Osaliste nimetamisel ja kategoriseerimisel kummagi presidendi kõnedes olulisi erinevusi esile ei tulnud.

\section{Interpersonaalse funktsiooni analüüs}

Interpersonaalse funktsiooni juures analüüsiti nii suhtlus- kui ka suhtumistasandit. Suhtlustähenduse juures vaadeldi kõnede personaalsust, pöördumisi kuulajate poole ja diskursuserolle. Suhtumistasandi analüüsil 
keskenduti MAAILMA kujutamisel ilmnenud läbivamatele hoiakutele uusaastakõnedes.

Suhtlustähenduse all vaadeldud mina-osaliste analüüsil selgus, et mina-deiksise või ainsuse 1. pöörde kaudu väljendati kõnelejat president Meri kõnedes 82 korral, president Rüütli kõnedes aga tunduvalt vähem 28 korral. President Meri sage mina-vormi kasutus osutab, et autor näitab ennast tekstiga tugevalt seotuna, seega võrreldes president Rüütli kõnedega oli Meri keelekasutus isiklikum, president Meri kõned olid personaalsemad kui president Rüütli omad.

Mina-vormi kasutussageduse suurenemist võis nii Meril kui ka Rüütlil täheldada eeskätt just kõnede algus- ja lõpuosas kuulajate poole pöördumisel. Presidentide võrdluses ilmnes, et kui Meril esines nendes osades enam mina-vormis pöördumist, siis Rüütli kõnedes kasutati samades funktsioonides rohkem impersonaalsemat väljendumist. Kuna isikuline tegumood mõjub konkreetsemalt kui umbisikuline, võib ka kuulajate kõnetamise analüüsi põhjal järeldada, et president Meri kõned on konkreetsemad. Seega selgus artiklis valitud keelevahendite vaatlusel, et võrreldes president Meri ja president Rüütli uusaastakõnesid, on Meri kõned mõnevõrra dünaamilisemad, konkreetsemad ja personaalsemad.

Mõlema presidendi mina-osalised esinesid suuremalt jaolt aktiivsetes rollides, president Meri 82 rollist olid aktiivsed 68 ja president Rüütli 28 mina-vormist olid aktiivses rollis 27. Enim esinevaks protsessiliigiks aktiivsete rollide puhul olid mõlemal mentaalsed protsessid, sealjuures leidus kõige rohkem intentsionaalseid protsesse, millega väljendati tahtmisi, soove ja soovitusi. Sageduselt järgmiseks kategooriaks olid verbaalsed protsessid, nii et kõnelejad esitasid ennast enamasti tahtjate, soovijate või rääkijatena (näited 25, 26, 27).

(25) Tahaksin, et mõistaksite lihtsat tõde .. (Meri 1994)

(26) Soovingi, et eeloleval aastal hooliksime rohkem igast lapsest. (Rüütel 2005)

(27) Lõpuks ütlen teile aitäh heade tegude, mõtete ja soovide eest .. (Rüütel 2004)

Diskursuserollidest esines president Meri kõnedes rohkem õpetaja rolli, milles kõneleja jagas korraldusi ja soovitusi. Sellele viitasid kohustuslikkust rõhutavad modaalverbid (modaalverbidest esineski Meril enim 
pidama-verb), otsesed pöördumised kuulajate poole ning küsimuste esitamine ja neile ise vastamine (näited 28, 29, 30).

(28) .. peame õppima mõistma, mis on riik. (Meri 1993)

(29) Kui põhiseadus töötab, mida ta siis toodab? Mida ta toodang maksab? Kes on selle toodangu ostja ja kelle taskusse läheb toodangu hind? Ma vastan teie küsimustele: põhiseadus toodab stabiilsust. (Meri 1995)

(30) Küsige enda käest, kas teis elab riigimehelik suhe Eesti Vabariiki? Kas te olete üldse selle peale mõelnud? (Meri 1996)

President Rüütli kõnedes domineeris teadja roll, millele viitasid kindla kõneviisi väitlaused. Teadja rollis olles andis president kuulajatele informatsiooni ning vahendas oma teadmisi ja arvamusi (näited 31, 32).

(31) Viimased avaliku arvamuse küsitlused näitavad, et referendumi korral ei kõhkleks me oma valikus Euroopa Liidu kasuks. (Rüütel 2002)

(32) Eesti riik on pakkunud oma abi õnnetuse ohvritele ja teeb seda kindlasti ka edaspidi. (Rüütel 2004)

Suhtlustähenduse analüüs näitas, et üldiselt eelistasid mõlemad kõnelejad jääda kuulajate kritiseerimisel ebamääraseks, mida saab tõlgendada positiivse viisakuse strateegiana. Võis täheldada, et president Meril esines rohkem meie-deiksise kaudu kritiseerimist (näide 33) ja president Rüütlil umbisikulises vormis kriitikat (näide 34). Mõlemad esitusviisid olid kantud soovist kriitikat pehmendada, Meri puhul ka ennast kriitika objektina näidates, Rüütli puhul kriitika objekti ähmastades.

(33) Kahjuks õpime aeglaselt, laisalt ja vastumeelselt. (Meri 1995)

(34) See on võimalik, kui mõistetakse, et valitsemine tähendab eeskätt vastutust mitte iseenda, oma erakonna või huvirühma, vaid Eesti riigi ees. (Rüütel 2001)

Kuulajate kõnetamiseks kasutatav sõnavara oli mõlemal presidendil positiivne ja emotsionaalne, seeläbi konstrueeriti kuulajaid kui kõnelejatele olulisi ja lähedasi isikuid (näited 35, 36). Kuulajate tunnustamine väljendus nii Meri kui ka Rüütli kõnedes sageli veel kuulajate tänamise kaudu. Kollektiivse identiteedi konstrueerimisel omistati kuulajatele uusaastakõnedes enamasti patriotismi, aga ka töökust (näited 37, 38). 
(35) Armsad kaasmaalased Eestis ja maailmas! (Meri 1994)

(36) Aga tahan teid, head sõbrad, tänada sellegi eest .. (Rüütel 2002)

(37) Tahan teid riigipeana tänada optimismi ja Eesti-meelsuse eest, mida olete ilmutanud läinud aastatel. (Rüütel 2003)

(38) .. mida olete möödunud aasta kestel oma igapäevase raske tööga ja raskusi trotsides Eesti Vabariigi heaks teinud. (Meri 1994)

MAAILMA kujutamisel ilmnenud hoiakute analüüsis selgus, et mõlema presidendi kõnedes esines läbivalt positiivne suhtumine Euroopasse ja Euroopa Liiduga seonduvasse. Euroopa Liiduga liitumisest rääkides esindati ainult pooldavat vaatepunkti, mida võib pidada kuulaja juhtimiseks vastava valiku poole (näide 39). Läbivatest negatiivsetest hoiakutest tuli esile president Meri kõnedes ilmnev suhtumine Vene aega, mil Eesti kuulus veel Nõukogude Liidu koosseisu (näited 40, 41). President Rüütli kõnedes võis selles aspektis märgata suhtumise muutust (näide 42). Hoiakute väljendamiseks kasutati asjakohast leksikat, võrdlusi ja metafoore.

(39) Nii liitumist NATO kui Euroopa Liiduga võib võrrelda kõigi nende kannatuste lunastamisega, mis meie rahvas on oma ajaloos üle elanud. (Rüütel 2002)

(40) Eesti Vabariik on tõusnud Vene okupatsiooni haigevoodist jalule .. (Meri 1994)

(41) Äratagem endas hetkeks Vene võimu aegsed mälestused Poliitbüroost, kes võis käigult vastu võtta otsuseid tervete rahvaste küüditamisest Siberi metsadesse või Kesk-Aasia kõrbetesse või määrata, et Eesti tuleb ümber kujundada üleliiduliseks fosforiidikaevanduseks või sigalaks. (Meri 1994)

(42) Ma loodan, et suudame oma minevikku käsitleda üha kompleksivabamalt, liigsete emotsioonideta ja mustvalgetest lihtsustatud skeemidest hoidudes... Erinevuste võimendamine ei lase aga vanadel haavadel paraneda. (Rüütel 2004)

Mõlema presidendi kõnesid läbis MAAILMA representeerimisel empaatia noorte, laste ja vanemate inimeste suhtes. Sageli rõhutati nende kokkukuuluvust kõneleja ja kuulajatega, asetati nad tunnustatavate rolli või seostati perekonnadiskursusega. Eri vanuserühmade empaatilist käsitlemist uusaastakõnedes võib tõlgendada soovina leida ühisosa võimalikult suure hulga kuulajatega ning perekonnadiskursuse osaliste (ema, isa, 
lapsed, vanaisad, vanaemad, perekond) sagedase sissetoomise eesmärk võis olla soov eeldatavate ühiste perekondlike väärtuste kaudu kuulajaid oma vaatenurka kaasa haarata.

\section{Kokkuvõte ja järeldused}

Kokkuvõttena võib tõdeda, et nii tähistus- kui ka interpersonaalsel tasandil esines president Meri ja president Rüütli uusaastakõnedes sarnaseid jooni. Aktiveeritud ja passiveeritud protsesside puhul domineerisid mõlema presidendi kõnedes materiaalsed protsessid, millest omakorda moodustasid enamiku abstraktsed tegevused.

Nimetamata primaarse osalisega protsesside uurimisel selgus, et mõlema presidendi kõnedes ilmnes osalise nimetamata jätmist kontekstides, kus anti kuulajatele korraldusi või kus neid manitseti. Osalise väljajätmine lubas kõnelejal tugevamaid hinnanguid esitada, samas võimaldades kuulajatel end vähem puudutatuna tunda. Ka suhtlustähenduse analüüsis tuli esile, et üldiselt eelistasid mõlemad kõnelejad kuulajate kritiseerimisel ebamääraseks jääda, mida saab tõlgendada positiivse viisakuse strateegiana.

Meie viiteala analüüs näitas, et põhiliselt taheti meie-vormiga rõhutada presidendi, kuulajate ja riigi kokkukuuluvust, tekitada rahvuslikku ühtekuuluvustunnet. Presidendid püüdsid luua ühist identiteeti, mis aitaks kuulajatel end väljendatud protsessidest osavõtjatena tunda. Meievormiga sai esitada omi seisukohti meie omadena ja näidata end rahva nimel tegutsejana.

Osaliste vaatlusel ilmnes, et MAAILMA esitati kõnedes enamikul juhtudel aktiivses rollis, meie-osalist suhteliselt võrdselt nii tegutsejana materiaalsetes protsessides, kogejana mentaalsetes protsessides kui ka seisundis olevana suhteprotsessides. Eesti kaudu determineeritud osalised seostati enamasti seisundiprotsesside ja passiivsete konstruktsioonidega.

Mõlema presidendi mina-osalised esinesid valdavalt aktiivsetes rollides, sealjuures enim esinevaks protsessiliigiks olid mentaalsed protsessid, milles kõnelejad väljendasid oma tahtmisi, soove ja soovitusi.

Kuulajate poole pöördusid mõlemad presidendid positiivse ja emotsionaalse sõnavara kaudu, näidates neid seeläbi endale oluliste ja lähedaste isikutena. Kollektiivse identiteedi konstrueerimisel omistasid kõnelejad kuulajatele patriotismi ja töökust. 
Suhtumistasandil kerkis mõlema presidendi kõnedes läbivalt esile positiivne suhtumine Euroopasse ja Euroopa Liitu, millega liitumisest rääkides esindati ainult pooldavat vaatepunkti ja selle kaudu mõjutati ka kuulajaid vastava valiku poole. Ühiste joontena läbisid uusaastakõnesid veel empaatia noorte, laste ja vanemate inimeste suhtes, mida võib tõlgendada soovina leida ühisosa võimalikult suure hulga kuulajatega, ning perekonnadiskursuse osaliste sissetoomine, mille eesmärk võis olla kuulaja mõjutamine eeldatavate ühiste perekondlike väärtuste kaudu.

Kuigi presidentide uusaastakõned olid paljude sisuliste ja tekstiliste tunnuste poolest sarnased, saab välja tuua ka personaalseid tekstitunnuseid. Artiklis vaadeldud protsesside analüüs osutab, et tänu aktiveeritud verbivormide suuremale kasutusele on president Meri kõned dünaamilisemad kui president Rüütli kõned. Suhteprotsesside ja mentaalsete protsesside osakaal näitab, et seisundite kirjeldamist oli rohkem president Meri kõnedes ning oma mõtete, tunnete ja soovide väljendamist president Rüütli kõnedes.

Kuna protsessi primaarne osaline jäeti sagedamini nimetamata Rüütli kõnedes, saab sellele tuginedes pidada president Meri kõnesid konkreetsemaks ja president Rüütli kõnesid abstraktsemaks. Sama järelduseni viis kuulajate kõnetamise uurimine, mille puhul Meri kõnedes eelistati rohkem isikulist ja Rüütli kõnedes enam umbisikulist väljendust. Diskursuserollidest esines Meri enim õpetaja rollis ning Rüütel pigem teadja ja sõnumi edastaja rollis.

Suhtlustähenduse uurimisel ilmnes, et president Meri oli kõnedes personaalsem, kasutades rohkem mina- ja meie-vormi. Ka kriitika tegemisel esines Meril sagedamini meie-deiksise kaudu kritiseerimist ja president Rüütlil umbisikulises vormis kriitikat. Seega selgus artiklis valitud keelevahendite analüüsil, et võrreldes president Meri ja president Rüütli uusaastakõnesid, on Meri kõned mõnevõrra dünaamilisemad, konkreetsemad ja personaalsemad. 


\section{Kirjandus}

Fairclough, Norman 1989. Language and Power. London: Longman.

Fairclough, Norman 1995. Media Discourse. London: Arnold.

Halliday, Michael Alexander Kirkwood 1994. An Introduction to Functional Grammar. $2^{\text {nd }}$ edition. London: Anold.

Kasik, Reet 2002. Lingvistiline tekstianalüüs. - Teoreetiline keeleteadus Eestis. Toim. Renate Pajusalu, Ilona Tragel, Tiit Hennoste, Haldur Õim. (= Tartu Ülikooli üldkeeleteaduse õppetooli toimetised 4.) Tartu: Tartu Ülikooli Kirjastus, 74-88.

Kasik, Reet 2008. Meediateksti analüüs: eesmärgid ja metoodika. - Tekstid ja taustad V. Meediatekstide keelekasutus ja selle sotsiokultuurilised taustad. Toim. Reet Kasik. Tartu Ülikooli eesti keele osakond. Tartu: Tartu Ülikooli Kirjastus, 10-43.

Kukk, Inga 2001. Eesti rahvuspoliitika osalised ajalehetekstides - kriitiline tekstianalüüs. - Keele kannul. Pühendusteos Mati Erelti 60. sünnipäevaks 12. märtsil 2001. Koost. ja toim. Reet Kasik. (= Tartu Ülikooli eesti keele õppetooli toimetised 17.) Tartu: Tartu Ülikooli Kirjastus, 146-165.

Leeuwen, Theo van 1996. The representation of social actors. - Texts and Practices. Readings in Critical Discourse Analysis. Ed. by Carmen Rosa Caldas-Coulthard, Malcolm Coulthard. London \& New York: Routledge, 32-70.

Pajusalu, Renate 1999. Deiktikud eesti keeles. (= Dissertationes philologiae estonicae Universitatis Tartuensis 8.) Tartu: Tartu Ülikooli Kirjastus.

Zupnik, Yael-Janette 1994. A pragmatic analysis of the use of person deixis in political discourse. - Journal of Pragmatics 21, 339-383. doi:10.1016/0378-2166(94)90010-8.

Maria Tuulik

sõnaraamatute osakond

Eesti Keele Instituut

Roosikrantsi 6

10119 Tallinn

Maria.Tuulik@eki.ee 


\title{
Similarities and differences between presidential speeches: critical text analysis
}

\author{
Maria Tuulik
}

The aim of the article is to explore the impact of the New-Year speeches by two presidents and their methods of communicating with the audience from the viewpoint of text analysis. The article analyses speeches by Lennart Meri from 1992 to 1996 and Arnold Rüütel from 2001 to 2005. The representation of actors and processes was analysed as the ideational function, and communication between the presidents and the audience was studied as the interpersonal function.

The speeches of both presidents favoured material processes; hence, both presidents represented participants mostly in situations of doing and acting or, more generally, in situations related to motion and changing. The second most frequent type of processes in Meri's speeches was relational processes and in Rüütel's speeches mental processes. Thus, Meri referred more to states, and Rüütel referred more to thoughts, feelings, and wishes.

Analysis of active and passivized processes showed that passive processes constitute $12 \%$ of president Rüütel's and $6 \%$ of president Meri's processes. As active processes enhance the dynamism of the style of the text and passive forms make it more static, one might claim that President Meri's speeches were more dynamic and President Rüütel's speeches more static.

Processes with an unmentioned agent constituted 7\% of President Meri's and $10 \%$ of President Rüütel's processes. And as omission of the primary actor was more common in Rüütel's speeches, it can be concluded, that President Meri's speeches were somewhat more concrete and President Rüütel's speeches somewhat more abstract. The speeches of both presidents showed that the agent was not mentioned much more often in passive processes.

The analysis of the interpersonal function showed that President Meri's speeches revealed more I-you level of communication and President Rüütel's speeches more impersonal addresses. Thus, one might claim that Meri's speeches were more personal and Rüütel's speeches more impersonal.

Keywords: text linguistics, stylistics, functional grammar, politeness strategies, deixis 